\title{
Empirical Study of the Implementation of $M$ - Learning in Takoradi Technical University
}

\author{
${ }^{1}$ Louisa Sheeta Arthur, ${ }^{2}$ Frank Amoani Arthur (Corresponding Author), ${ }^{3}$ Angela Aba Otchere. \\ ${ }^{1,2,3}$ Faculty of Applied Sciences, Department of Information and Communication Technology, Takoradi \\ Technical University, P.O. Box 256, Takoradi - Ghana \\ E-Mail: frank.amoani.arthur@tpoly.edu.gh
}

\begin{abstract}
The use of mobile phones in the world especially most developed countries have become part of everyday life and majority of people carry them all the time (Smura et al., 2009). Students in tertiary institutions are noted to be among the highest users of mobile devices and since m-learning enables mobility and mobile learning, allowing teaching and learning to extend to spaces beyond the traditional classroom, the researchers conducted an empirical study on the possible implementation of m-learning in Takoradi Technical University.

The researchers used the variables of Technology Acceptance Model (TAM)-perceived ease of use, perceived usefulness, attitude towards use and behavioural intention to use as the bases for modelling the questionnaire and it was found out that almost all $(99.3 \%)$ of the students are aware of m-learning but about only a third (28.6\%) uses the mobile devices for m-learning while $37.1 \%$ of the respondents use their mobile devices for social media. The researchers therefore concluded it is highly possible to implement m-learning in Takoradi Technical University with little or no training for students if there is enough education.
\end{abstract}

Keywords: perceived ease of use, usefulness, attitude toward use, behavioural intention and m-learning.

DOI: $10.7176 / \mathrm{JIEA} / 8-1-05$

\subsection{Introduction}

Using portable computing devices (such as iPads, laptops, tablet PCs, PDAs, and smart phones) with wireless networks or internet has become the order of the day with most of students at the tertiary institutions using this electronic device either for entertainment or for learning purposes. Consumers have become stacked to the using of Smart phones or mobile devices and this has boosted the smart phone business and increased the demand in the market. With the popularity and functions offered in the smart phones, there has been an increase in demand (Park and Chen, 2007). According to Smura et al. (2009), the use of mobile phones in the world especially most developed countries have become part of everyday life and a majority of people carry them all the time.

Students at tertiary institutions are noted to be among the highest contributors of mobile devices and this has contributed to the increasing number of mobiles device or smart phone sales (Jacob and Isaac, 2008). Most of the functionalities in these devices are designed to help users in their daily life especially students and business men or women. M-learning enables mobility and mobile learning, allowing teaching and learning to extend to spaces beyond the traditional classroom. Within the classroom, mobile learning gives instructors and learners increased flexibility and new opportunities for interaction. M-learning or mobile learning is defined as "learning across multiple contexts, through social and content interactions, using personal electronic devices (Khaddage et al, 2009).

Mobile learning technologies offer a flexible approach to learning for both facilitators and students. A more flexible approach to learning. Technologies for $\mathrm{m}$ - learning include handheld computers, MP3 players, notebooks, mobile phones and tablets. The basic use of M-learning technology is to assist the learner to use these devices outside the classroom to facilitate learning (Brown, 2003). It is convenient to use M -learning because it can be accessed anywhere. M-learning also brings strong portability by replacing books and notes with small devices, filled with tailored learning contents. The use of mobile phones, tablets, iPads, etc. are preferred by 
students at the tertiary institution because it enhances learning, group collaboration among students through communication applications, interactive displays, and video features.

According to Callaway and Ewen (2009), students who download podcast lectures at the end of the day obtain higher results in their exams than students who only attend lectures in person and only take notes. Hence, this research aims to assess students' dependence on smart phones and its impact on their purchase behaviour. This research assesses the use of m-learning at the tertiary institution. Whether it is convenient for students to use, whether it influences their learning and whether the students have keen interest in the mobile learning. This research also examines the type of mobile learning technology available to these students at the tertiary level.

Singh (2010) stated that the current generation prefer flexible learning environment because of the busy nature of their lives. The traditional classroom face to face teaching and learning is unfavourable to the current generation therefore m-learning has been seen to the main way out for those who want to educate themselves and also continue with their busy lifestyles. The economic advantage of m-learning relative to the traditional classroom type of learning was highlighted as the impact that the innovation is having on the world of education (Sharples, 2000).

In spite of these benefits and the advantage m-learning brings into the world of education, tertiary educational institutions such as the Takoradi Technical University in Ghana especially seem not to have heard of these benefits and so has not taken steps to implement m-learning. In order for a mobile learning initiative to be employed at the university level, students and faculty must see a need for educational use. In addition, both students and faculty must be ready and open to the potential benefits of a change in the teaching and learning environment (Quinn, 2000). TTU currently runs it education solely on the classroom face to face approach where students must of a necessity come to class for teaching. This is currently creating such problems as truancy especially on the part of the working class and also difficulty in learning.

The questions therefore that needs to be asked; are student of the Takoradi Technical University ready for $\mathrm{m}$ learning and what will be the likely impacts of learning on students and the institution should it be implemented? The idea of employing the use of mobile devices in education seems as if it came up recently, Najmi and Lee (2009) in their research stated that the concept of employing mobile devices and technology in the educational sector was discussed as far back as 1960. Keegan (2005) in his study, described the "dynabook" which was a mobile device that could function as a reading tool as well. Lenhart et al., (2010) further states that, in the United States of America alone, $85 \%$ of the adult population own cell phones with the largest share among the younger generations. According to a survey by the Ghana Statistical Authority (2014), Ghana has over 7 million mobile phone subscribers which give the impression that there are over 7 million cell phone owners in the nation and just like the United States of America, the majority of these owners or subscribers are the younger generations. Globally, Mobithink Mobile Statistics (2015) estimated that the number of mobile phone subscribers was about $60 \%$ of the total population. In the tertiary education sector, Kennedy et al. (2006) stated that over $97 \%$ of all university students born after 1980 were owners of mobile phones. Increasingly, mobile phone users especially in the tertiary institutions use their phones to access diverse information on the internet which make the university or the tertiary educational arena a very good area for the application of mobile technology whether for educational purposes or any other purposes.

\subsection{The Concept of M-Learning}

The mobile learning from its early days was thought of as a form of e learning by many researchers with some of the early researchers describing the concept as a form of e learning using mobile technology (Doneva, 2006; Georgiev et al, 2004 and Quinn, 2000). But the recent development of the concept has positioned mobile learning on a different platform separate from e -learning.

Even though the concepts of e-learning and m-learning have several similarities, a major difference that make $\mathrm{m}$ learning different is that while e-learning requires a specific work station to access and exchange educational information, m-leaning bring on beard learning at any given location and time. Education materials are access on mobile devices (Rosenberg, 2001).

\subsection{Definition of M-Learning}

Different definitions have been put forth by various authors on parameters such as mobility of the learners, mobile device applications and the relation between M-learning and E-learning. Naismith et al. (2004) in their 
definition of m-learning, stressed on the devices used for m-learning. They indicated that learning activities on mobile wireless devices such as smart phone, PDA, iPod, palmtop, laptop or even digital camera and USB constitutes m-learning. This definition falls short of features that make a learning activity m-learning which is the flexibility of location and time.

Georgieva, Smrikarov and Georgiev (2005), defined m-learning as use of mobile devices for learning activities anytime and anywhere. This definition stresses on location and time as the key features for characterising mobile learning. Learning anywhere and anytime constitutes mobile learning. The limiting aspect of this definition is the fact that it was silent on the devices that will make a learning activity m-learning. Keegan (2005) on the other hand, combined the features of the two definitions and indicated m-learning as any teaching and learning activity which makes use of devices such as PDAs, palmtops, handhelds and smart phones at any place and time. Specifically, Keegan (2005) eliminated laptops form his list because of his intention to ensure that $\mathrm{m}$-learning is properly associated with portable devices.

Doneva, Nikolaj and Totkov (2006) closely bridge the gap between e-learning and m-learning when they defined m-learning as an e-learning which is undertaken by means of mobile technology and wireless mobile devices. This definition reveals the origin of m-learning as e-learning. In differentiating e-learning from m-learning, they stated that it is based on mobile learning devices and technology to provide learning and teaching activities anytime and anywhere but e-learning extends to the use laptops, desktops and electronic libraries.

Liu and Han (2010) also described M-learning as an educational channel for the delivery of teaching and learning at the convenience of both the learner and the teacher. From all the views reviewed above, m-learning can be said to be the provision of an anywhere and anytime learning and teaching activities by means of mobile devices such as PDAs, smart phones and wireless technologies.

The discussions above bring to bear the distinction between the various forms of non-traditional learning namely distance learning (d-learning, e-learning and m-learning). This section of the study discusses the differences between these forms of learning.

Figure 1.1: The place of M-learning as part of E-learning and D-learning

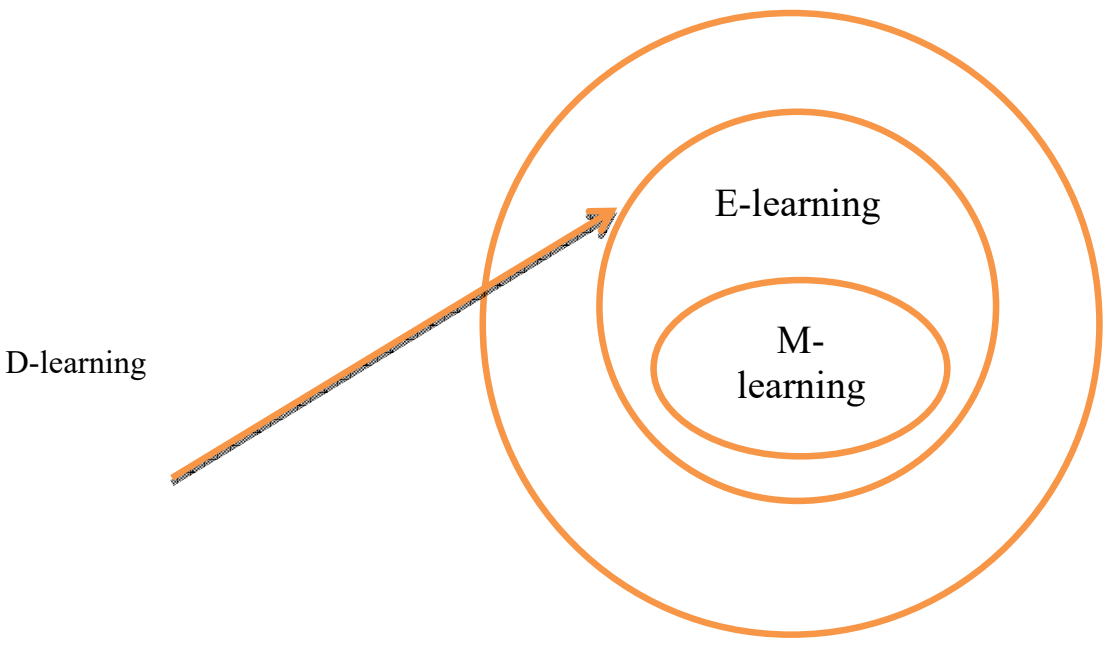

Source: Brown, 2003, Georgiev et al., 2004 and Peters, 2007

According to Brown, (2003), Georgiev et al., (2004); Peters, (2007), three main factors are identified as the underlying factors that differentiate these forms of education. These factors are technology, learner access and mode of communication.

D-learning involves provision of a face to face education on sites which is far away from the main campus. Even though it may involve some form of technology such as the use of internet for various researches d-learning is actually not technology inclined. Its main focus is learning at a distant centre from the main campus (Brown, 2003, Georgiev et al., 2004). 
E-learning on the other hand involves the provision of education through an electronic medium. This form of education is mostly face-to-face and in a confined location such as a classroom but with the teacher in a different place and the learner also in another place and the two of them connected by means of internet technology (Brown, 2003). E-learning is undertaken at predetermined times and locations which means it cannot be undertaken anywhere and anytime as in the case of m-learning. E-learning therefore is regarded an offshoot or subset of d-learning (Brown, 2003; Georgiev et al., 2004; Peters, 2007). M-learning activity is an anytime and anywhere form of teaching and learning by means of mobile devices and technology. Considering it similarity with e-learning m-learning is also seen as a subset of e-learning.

\subsection{Motivation and Opportunity of M-Learning}

Mobile handsets have inherent characteristics that make them very convenient and appropriate as tools for education in terms of providing exploring and sharing learning contents. These inherent features include portability, functionality, ubiquity, utility and connectivity (Pachler, Bachmair and Cook, 2010). Such features of mobile phones make them ideal instrument for use as educational tools. More especially the ability of mobile phones to display some similarities of desktop computer such as ability to process and store data also makes it more convenient for use as education platforms (Fetaji and Fetaji, 2009).

As side these features, the relatively lower cost when compared to computers means that mobile devices as education tools are preferable to computers. According to Kloper, Squire, and Jenkins (2002), these features have formed the basis for educational software developers to focus on mobile devices as medium for teaching and learning. Besides, continuous development of mobile devices is gradually bringing it closer to standard desktop computers and so in some few years to come using mobile devices will offer the same if not more features and experience as desktop or laptop computers (Fetaji and Fetaji, 2009). However, Khaddage, Lanham and Zhow, (2009) postulated that some internal features of mobile devices such as messaging, games, internet access and multimedia convergence are some of the reasons why mobile devices are not attracting attention of software developers to its use as learning and teaching tools.

Mahamad, Ibrahim and Taib, (2010) argued that the increase in attraction of mobile devices to student is also a motivational factor for the development and promotion of mobile learning in the university level. Another factor that is providing opportunity for the development and promotion of mobile is the view expressed by Laurillard (2007) when he indicated that mobile devices and technology provide student the following social life interaction, control over their learning and also learning in contexts and continuity between contexts.

\subsection{Students' Readiness for M-Learning}

The success of m-learning technology in any institution is dependent on the readiness of the students to accept the program (Cheon et al., 2012). The increasing usage of mobile devices and wireless technologies in higher educational institutions around the globe has ensured that institution willing to implement m-learning have very little opposition from students.

Mobile learning makes use of mobile devices such as PDAs, tablet and smart phones which happens to be the same devices that students have high interest in and are willing to purchase. Since the need for mobile devices as part of m-learning will not be demanded by the institution implementing the technology, students according to Mahamad, Ibrahim and Taib, (2010) are automatically ready in this sense for the usage of the technology. Most universities already apply e-learning program where students have access to materials and also learn through electronic means by extending the same electronic learning program to their mobile devices, students have been observed to highly appreciate the benefit of m-learning (Motiwalla, 2007).

Lam et al., (2011) also stated that compared to the pre-university level, university students easily accept mlearning because of the higher ownership and usage of mobile devices in these places and also their familiarity with e-learning. They therefore concluded that the level of readiness in institutions of higher learning for $\mathrm{m}$ learning is very high.

Another research conducted by Abas, Peng and Mansor (2009) to determine the perception of students towards mobile learning in developing countries revealed that students in the Open University Malaysia (OUM) were of the opinion that they were not only ready for mobile learning but they were mobile learners. This study also found that students thought of m-learning technologies as good for ensuring that they are able to organise themselves and learn effectively. 
In their research in the readiness of students for m-learning technology, Trifonova, Georieva and Ronchetti (2006) surveyed the views of students in the University of Trento, Italy, and the University of Ruse, Bulgaria. Their studies revealed that the largest share of the students population in the two universities have access to mobile devices and are familiar with one form of e-learning technology or the other. But the attitude of students towards m-learning was determined to be dependent on the level of familiarity and experience with e-learning technologies. Those who have had positive experiences with e-learning technology were seen to favour $\mathrm{m}$ learning whiles those whose experience with e-learning were not good opposed the implementation of the program.

Comparing the finding of this research to the Ghanaian context, based on the availability and ownership of mobile devices, students of higher educational institutions in the country can be said to be ready for the technology. Cost wise, only a relatively low percentage of the students' population compared to the findings of the study will be in favour of the technology because of the relatively high cost of mobile devices that can support such technology and also relatively high cost of mobile services in Ghana compared to the European country.

The examples discussed above give leads to the conclusion that, m-learning technology is already receiving high level of acceptance from students in places where they have been implemented. The results show that this situation is so because of the widespread of mobile device usage among students within the higher educational institutions and also the already existing e-learning technologies in these places. Acceptance of this technology is also affected by other factors such as gender, cost of mobile devices and mobile services as well as prior experience with e-learning.

\subsection{Challenges of M-Learning}

Aside the huge potential of m-learning to positively affect the higher educational sector in Ghana, there are certain limitations that are associated with the implementation and development of the technology. Among these limitations are the design, Users' psychological limitation, safety, security and implementation cost, mobility and learning over time.

According to Hashemi et al (2011), the designs of mobile devices have inherent limitations that can influence the overall performance of m-learning. Most mobile devices have small screen and memory size, limited keyboard space and battery life which impede smooth usage of mobile devices as effective m-learning tool. Barker et al. (2005) further highlighted the limited resolution of most mobile devices compared to personal computers as a key technical limitation that affect the effective implementation of m-learning.

The predisposition of users (students) towards the main function of mobile devices has also been identified as a key factor that can negatively influence the implementation and use of mobile-learning technology. Wang, Wu and Wang, (2009) postulated that some students still hold the view that mobile devices are mainly for entertainment, social networking and interaction and would not consider it as favourable devices for educational purposes.

It is an arguable fact that mobile devices are easy to lose, subject to technical damages that would cause malfunctioning and more likely to be stolen. Barker et al. (2005) argued that mobile devices used as teaching and learning tool would require training of both students and teachers. This would come with the cost of setting up the teaching and learning environment, maintaining and training other stakeholders that would facilitate its implementation which is likely to affect the ability of higher institutions to begin.

The idea of m-learning ensures that teaching and learning can all take place anywhere and anytime. This same inherent advantage would result in a situation of distance relationship between the same students and their teachers (Barker et al. 2005). Besides, m-learning provides the ability to access information about the user's environment, which can cause privacy concerns therefore effective mobile devices are needed to organize and reflect the m-learning experience of lifelong learners.

\subsection{Methodology}

The Technology Acceptance Model (TAM) ensures that the relationship between the impact of external variables (system design characteristics, training, computer self-efficacy) on internal beliefs, attitude toward use, behavioural intentions and actual system use (Ibrahim and Jaafar, 2011). The Technology Acceptance Model 
(TAM) has received increased in attention because of the fact that it is relatively simple model to use and can also be applied in different context when it comes to the application of technology (King and He, 2006).

Figure 1. Theoretical Framework of Technology Acceptance Model (TAM)

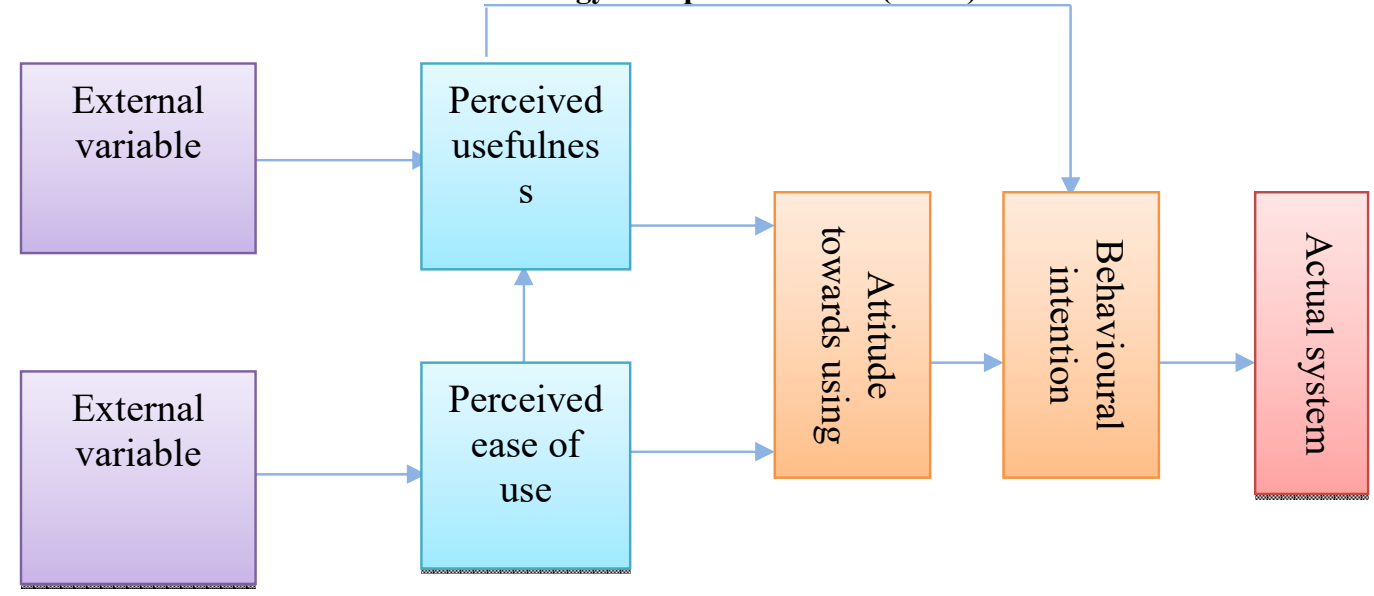

Source: Technology Acceptance Model (TAM) (Davis, 1989)

This study was based on the exploratory research design. This method involves probing a new topic / angle of an issue or event. It seeks to build theory rather than test it, and can also fill in a gap in existing theory (King and $\mathrm{He}, 2006)$. It enables a researcher to gain new insights about a particular phenomenon. Barker et al. (2005) suggest that the aims of an exploratory research method include to: construct a representation of events, develop new thought, conjectures or hypotheses; discover the problems that exist within the phenomena and determine the feasibility of conducting research. Although, the study employed the exploratory research design, the variable of TAM-perceived ease of use, perceived usefulness, attitude towards use and behavioural intention to use were the bases for modelling the questionnaire.

Kloper et al (2002) advises that the aim of the inquiry and use of the findings should govern a researcher's decision on the choice of qualitative or quantitative approaches. They further postulate that depending on the type of study embarked on, a researcher may need to use both qualitative and quantitative approaches in a study because such approach benefits from the advantages associated with each of the methods while at the same time avoiding the weaknesses of each hence the study employing quantitative research approach due to the fact that questionnaires were used as the main instrument for data collection.

The total staff population of the university is one thousand one hundred and twenty-eight (1128) which is made up of four hundred and sixty-seven (467) academic staff with the rest making up the non-academic portion of the school. The student population of the university is five thousand eight hundred and sixty-seven (5867). Due to time constraint and considering the huge number of the staff and student population of the university, the study therefore employed the convenient sampling technique to settle on a staff size of fifty (50) of all whom are academic staff members because of their direct involvement in the learning activities in the university and student population of two hundred (200).

The questionnaires used for the study comprised of two main sections. The first section required the respondents to provided information on their bio data while the second section was made up of questions that allowed the respondent to express their views regarding the possibility of implementing m-learning in Takoradi Technical University. The likert scale of 1-5 where 1 represented strongly disagreed and 5 represented strongly agreed was used to allow the respondents indicate their opinion regarding the various issues raised by the researcher. The questionnaires were administered personally by the researcher and the responds to the questionnaire were analysed using SPSS v 21. The results were presented in the form of tables and further analysed using T-Test distribution to establish the certainty of the responds. 


\subsection{Results and Discussion of Findings}

Molla, A. Heeks, R. and Boateng, R. (2009) postulate that males are more likely to adopt and use technology than females. In this view, the gender of the respondents were accessed and the study revealed that there were more male respondents $(52 \%)$ than female $(49.9 \%)$. The age distributions of the respondents were also accessed and the results are showed in table 1 below.

Table 1: Age Distribution of Respondents

\begin{tabular}{lcc}
\hline \hline Age & Frequency & Percent \\
$18-25$ years & 40 & 28.6 \\
$26-30$ years & 56 & 40.0 \\
$31-35$ years & 28 & 20.0 \\
Above 35 years & 16 & 11.4 \\
Total & $\mathbf{1 4 0}$ & $\mathbf{1 0 0 . 0}$ \\
\hline \hline
\end{tabular}

Source: Fieldwork, (2018)

According to Table 1, most (40\%) of the respondents were found in their late twenties. Almost Twenty - Nine Percent $(28.6 \%)$ of the respondents were aged between eighteen (18) and twenty-five (25) years, Twenty Percent $(20 \%)$ of the respondents were in the age group of $31-35$ years while about Eleven Percent $(11.4 \%)$ were above 35 years. The age ranges are fair distribution among staff and students who were the target for the survey.

Table 2: Mobile Devices used by Respondents

\begin{tabular}{lc}
\hline Devices & Percent \\
GSM phones & 10.7 \\
Smart Phones & 53.6 \\
Personal Digital Assistants (PDA) & 8.6 \\
Tablets PC & 27.1 \\
Total & $\mathbf{1 0 0 . 0}$ \\
\hline \hline
\end{tabular}

Source: Fieldwork, (2018)

As part of the researcher's quest to assess the extent of readiness of students of TTU for m-learning, the types of mobile devices used by the respondents were accessed and results are displayed in the table above. The study revealed that more than half $(53 \%)$ of the respondents were using Smart Phones, a little above twenty-seven Percent (27.1\%) were using Tablet PCs, about Eleven Percent (10.7\%) were using GSM Phones while 8.6\% of them were using Personal Digital Assistants (PDAs). The result indicates that majority of the respondents have the required gadgets needed for the introduction of m-learning in Takoradi Technical University (TTU).

Table 3: Type of Use of Mobile Devices by Respondents

\begin{tabular}{lcc}
\hline \hline Usage Type & Frequency & Percent \\
Phone Calls & 48 & 34.3 \\
Social Media and Interactions & 52 & 37.1 \\
Learning & 40 & 28.6 \\
Total & $\mathbf{1 4 0}$ & $\mathbf{1 0 0 . 0}$ \\
\hline \hline
\end{tabular}

Source: Fieldwork, (2018) 
The researcher also found out what respondents use their devices for and theses usage types were tabulated in Table 3 above. The result shows that most (37.1\%) of the students and staff of TTU uses their mobile devices for interactions on social media. A little above thirty-four Percent $(34.3 \%)$ used their mobile devices for voice communication while the remaining $28.6 \%$ used their mobile devices for direct learning purposes. This indicates that learning with mobile devices is on the lower side and the introduction of m-learning through vigorous sensitization would encourage the use of most mobile devices for m-learning.

Table 4: M-Learning Awareness among Respondents

\begin{tabular}{lcc}
\hline \hline Age & Frequency & Percent \\
Yes & 139 & 99.3 \\
No & 1 & 0.7 \\
Total & $\mathbf{1 4 0}$ & $\mathbf{1 0 0 . 0}$ \\
\hline \hline
\end{tabular}

Source: Fieldwork, (2018)

The researcher probed further the result which shown that only $28.6 \%$ of the students used their mobile devices for learning and sought to find out the m-learning awareness among respondents. In response, almost all (99.3\%) respondents admitted that they are aware that mobile devices can be used for learning but denied knowledge of $\mathrm{m}$-learning as the use of mobile devices for learning purposes. Only one $(0.7 \%)$ of the respondents said he is not aware that mobile devices can be used for learning. This affirms the assertion that mobile learning is feasible among the students of the Takoradi Technical University (TTU) if the awareness and sensitization is pursued with utmost urgency.

Probing further, a one-sample test on the position of student on m-learning was conducted at $95 \%$ confidence level and it was evident that the student had a significant level of capability to use m-learning and do not need any training to be able to use m-learning technology as part of their education TTU. The students however strongly agreed to the fact that the introduction of m-learning will significantly ensure that learning can be undertaken both inside and outside the classroom. They also indicated that learning will be significantly enjoyable and made easier should TTU implement m-learning. The implementation of m-learning is already been perceived by students to significantly contribute to the improvement in the grades of students, enhance communication between teachers and students and also ensure that the quality of the curriculum is significantly enhanced.

On the other hand, the respondents' view regarding the ability of m-learning to make learning mobile and collaborative also revealed that the implementation of m-learning will significantly ensure that students' learning becomes mobile and also collaborative. A mean response of 4.01 is an indication of a strong agreement on the part of the majority of the respondents and a significant value of $0.000<0.05$ obtained attest to this assertion. When implemented, m-learning would be seen to have the potential to significantly increase students' ability to study individually (self-study). A mean response of 4.01 and significant value of $0.000<0.05$ obtained for this assertion is a strong indication that majority of the respondents agree that the implementation of m-learning will have significant positive impact on the learning environment.

Notwithstanding the possibility of implementing the m-learning in TTU, the researcher sought to find out the possible factors that could impede the implementation of m-learning. The researcher found out the screen size of mobile devices was small enough to affect the smooth reading of large documents. The study also revealed that the batteries of these devices had short life span to be used as m-learning devices. The speed of internet connectivity was also agreed by majority of the respondents as slow enough to hamper the usage of m-learning technology if implemented. A mean response of 3.25 with a standard deviation of 0.990 obtained attest to the assertion. The views of the psychological factors that can challenge m-learning was also investigated and the results revealed that most students in TTU prefer the current face-to-face approach of teaching and learning to other forms of learning such as m-learning. This was evidenced by a mean response of 3.63 and a significant value of $0.008<0.05$ indicating that psychological factors are likely to significantly challenge the successful implementation of m-learning in TTU. 


\subsection{Conclusion and Recommendation}

In conclusion, the researcher assessed the perceived possibility of implementing Mobile Learning (M-Learning) in Takoradi Technical University using the variables of Technology Acceptance Model (TAM) proposed by Davis (1989). The researcher employed the exploratory research design using the variables of TAM thus perceived ease of use for the mobile devices, perceived usefulness for the m-learning process and attitude towards use and behavioural intention of students to use the modern style of learning.

The study established that most $(40 \%)$ of the respondents using the required instrument for m-learning were in their late twenties. This age group which forms majority of students affirms the researcher's findings of the possibilities of implementing m-learning in Takoradi Technical University. This age group was also observed to have used most of the required instruments among the respondents.

Although almost all (99.3\%) of the respondents were aware of m-learning, the study further informs that almost a third $(28.6 \%)$ of the respondents use their mobile devices for learning purposes but the majority $(37.1 \%)$ of the respondents who uses theirs for social media had some form of addiction for it than using it for m-learning. A vigorous sensitization would encourage them to use it for the new learning process.

In other to ascertain the possibility of implementing m-learning in technical universities, a one-sample test on the position of students on m-learning was conducted at 95\% confident level and it was evident that the students had a significant level of capabilities to use m-learning and do need little or no training to be able to use m-learning technology as part of their education in TTU. The students however strongly agreed to the fact that the introduction of m-learning will significantly ensure that learning can be undertaken both inside and outside the classroom. They also indicated that learning will be significantly enjoyable and made easier should TTU implement m-learning. The researcher therefore concludes that, it is highly possible to implement $\mathrm{m}$-learning in Takoradi Technical University with little or no training for students if there is enough education on m-learning. The outcomes of this conceptual study are recommended to Councils and Managements of Technical Universities to make informed decision on modern learning models that will improve learning among their students.

\section{REFERENCES}

Abas, Z. W., Peng, C.L. and Mansor, N. (2009). A Study on Learner Readiness for Mobile $\quad$ Learning at Open University Malaysia. In Proceedings of the IADIS International Conference Mobile Learning, 26-28 Feb, Barcelona, Spain, 151-157.

Barker, A., Krull, G. and Mallinson, B. (2005). A Proposed Theoretical Model for M-Learning Adoption in Developing Countries. Proceedings of the 4th World Conference on mLearning, mLearn 2005, October 2528, Cape Town, South Africa, 1-10.

Brown, T. H. (2003). The Role of M-learning in the Future of E-learning in Africa? In Proceedings of the 21st ICDE World Conference, Hong Kong, 1-12.

Callaway and Ewen (2009). The Essence of Reality. 'iTunes university' better than the real thing. New Scientist blog. Computers and Education (DOI: 10.1016/j.compedu.2008.11.004). Available at: https://www.newscientist.com/article/dn16624-itunes-university-better- than-the-real-thing/

Cheon, J., Lee, S., Crooks, S. M. and Song, J. (2012). An Investigation of Mobile Learning Readiness in Higher Education Based on the Theory of Planned Behaviour. Computer and Education. 59(3), 10541064 .

Davis, F. (1989) "User acceptance of computer technology: system characteristics of information technology”. MIS Quarterly, vol. 13 vol. pp. 319-340, March, 1989.

Doneva, R (2006). Towards Mobile University Campuses. International Conference on Computer Systems and Technologies (CompSysTech'2006). Available at: http://ecet.ecs.ru.acad.bg/cst06/Docs/cp/sIV/IV.3.pdf

Doneva P, Nikolaj N and Totkov H (2006) Creating a Powerful Learning Environment with Networked Mobile Learning Devices. Educational Technology Magazine, 47(3), 47-50. 
Fetaji, M. and Fetaji, B. (2009). Devising Usability Framework for Mobile Learning Software Solutions. In Proceeding of the International Conference on e-Education and e-Learning. June 22-26, Paris, France.

Georgiev, T., Georgieva, E. and Smrikarov, A. (2004). M-learning: A new stage of e-learning. In Proceedings of the International Conference on Computer Systems and Technologies - CompSysTech, 2004, Rousse, Bulgaria

Georgieva, E., Smrikarov, A. and Georgiev, T. (2005). A General Classification of Mobile Learning Systems. In Proceedings of the International Conference on Computer Systems and Technologies CompSysTech, June 16-17, 2005, Varna, Bulgaria.

Hashemi, M., Azizinezhad, M., Najafi, V. and Nesari, A, J. (2011). What is Mobile Learning and Capabilities? Procedia- Social and Behavioural Sciences, 30, 2477-2481.

Jacob, S. M. and Issac, B. (2008b). The Mobile Devices and its Mobile Learning Usage Analysis. In Proceedings of the International Multi Conference of Engineers and Computer Scientists, IMECS 2008, 1921 March, Hong Kong.

Ibrahim, R. and Jaafar, A. (2011). User Acceptance of Educational Games: A revised Unified Theory of Acceptance and Use of Technology (UTAUT). World Academy of Science, Engineering and Technology, $53,551-557$.

Keegan, D. (2005). The Incorporation of Mobile learning into Mainstream Education and Training. In H. van der Merwe and T. Brown (Eds.), mLearn 2005: 4th World Conference on Mobile Learning. Mobile technology: The future of learning in your hands. Cape Town, South Africa: mLearn, 1-17.

Kennedy et al. (2006). The Incorporation of Mobile learning into Mainstream Education and Training. In H. van der Merwe and T. Brown (Eds.), mLearn 2005: 4th World $\quad$ Conference on Mobile Learning. Mobile technology: The future of learning in your hands. Cape Town, South Africa: mLearn, 1-17.

Khaddage, F., Lanham, E. and Zhow, W. (2009). A Mobile Learning Model for Universities: Re- blending the current learning environment. International Journal of Interactive Mobile Technologies, 3(1), 18-23.

King, W. and He, J. (2006). A Meta-Analysis of the Technology Acceptance Model. Information and Management, 43(2006), 740-755.

Kloper, E., Squire, K. and Jenkins, H. (2002). Environmental Detectives: PDAs as a window into a virtual simulated world. In Proceedings for IEEE International Workshop on Wireless and Mobile Technologies in Education, 30 August, 95-98.

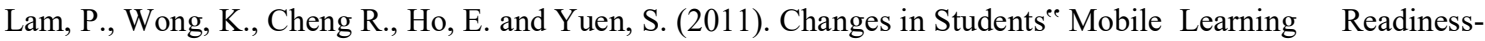
Comparison of survey data collected over a nine-month period. In Proceedings of the Global Learn Asia Pacific (Global learn 2011), 28 March, $\quad$ Melbourne, Australia, 180-189.

Laurillard, D. (2007). Pedagogical Forms for Mobile Learning. In Pachler, N (Ed.), Mobile Learning: Towards a Research Agenda. London, UK: WLE Centre, 153-175.

Lenhart P et al., (2010). Pervasive, Lifestyle-Integrated mobile Learning for Distance Learners: an Analysis and unexpected Results from a Podcasting Study. Open Learning, 22(3), 201-218.

Liu, Y. and Han, S. (2010). Understanding the Factors Driving M-learning Adoption: A literature review. Campus-Wide Information Systems, 27(4), 210-226.

Mahamad, S., Ibrahim, N, M. and Taib, S. (2010). M-Learning: A new paradigm of learning mathematics in Malaysia. International Journal of Science and Information Technology, 2(4), 76-86. 
Molla, A. Heeks, R. and Boateng, R. (2009) "Information Systems in Organizations: Categories Trends and Demonstration", ICITD, Southern University and University of Ghana UGBS- MIS (2009) class.

Motiwalla L.F. (2007). Mobile Learning: A framework and evaluation. Computers and Education, 49(3), 581596.

Najmi, K. and Lee, J (2009). Effects of Consumer Characteristics on their Acceptance of Online Shopping: Comparisons among different product types. Computers in Human Behavior, 24(1), 48-65.

Pachler, N., Bachmair, B. and Cook, J. (2010). Mobile Learning: Structures, agency, practices. $\quad$ New $\quad$ York: Springer.

Park, Y. and Chen, J. (2007).Acceptance and adoption of the innovative use of smartphone Industrial Management \& Data Systems, 107(9), pp. 1349-1365.

Peters, K. (2007). M-learning: Positioning educators for a mobile, connected future. The International Review of Research in Open and Distance Learning, 8(2), 1-17.

Quinn, T (2000). M-learning: Positioning educators for a mobile, connected future. The International Review of Research in Open and Distance Learning, 8(2), 1-17.

Rosenberg, M. J. (2001). E-Learning: Strategies for Delivering Knowledge in the Digital Age. $\quad$ New York: McGraw-Hill.

Sharples, M. (2000). The design of personal mobile technologies for lifelong learning. Computers Education.

Singh, M (2010). M-Learning: A New Approach to Learn Better. International Journal of Education and Allied Sciences 2 (2): 65-72.

Smura, T. et al (2009). Mobile data services in Finland: usage of networks, devices, applications and content, Int. J. Electronic Business, Vol. 9, Nos. 1/2, pp.138-157.

Trifonova A., Georieva, E. and Ronchetti, M. (2006). Determining Students ${ }^{\text {ee }}$ Readiness for Mobile Learning. In Proceedings of the 5th WSES international conference on E- ACTIVIES, 20-22 November, Venice, Italy.

Wang, Y.S., Wu, M. and Wang, H. (2009). Investigating the Determinants and Age and Gender Differences in the Acceptance of Mobile Learning. British Journal of Educational Technology, 40(1), 92-118. 